\title{
Independence of and Interactions between GABA-, Glutamate-, and Acetylcholine-Activated Cl Conductances in Aplysia Neurons
}

\author{
JacSue Kehoe ${ }^{1}$ and Catherine Vulfius ${ }^{2}$ \\ ${ }^{1}$ Laboratoire de Neurobiologie, Ecole Normale Supérieure, Paris 75005, France, and 2Institute of Cell Biophysics, Russian \\ Academy of Sciences, Pushchino, Moscow Region, 142292, Russia
}

In certain Aplysia neurons, glutamate, GABA, and acetylcholine (ACh) all elicit desensitizing $\mathrm{Cl}$-dependent responses. This fact and the finding that the glutamate and GABA responses "crossdesensitize" led to the suggestion (Swann and Carpenter, 1975; King and Carpenter, 1987) that the responses to these transmitters were mediated by the same receptor-channel complex.

This hypothesis is incompatible with the demonstration given here that the GABA- and glutamate-gated channels are clearly distinct; the GABA channel, but not the glutamate channel, shows outward rectification (Matsumoto, 1982; King and Carpenter, 1987, 1989) and is selectively blocked by intracellular sulfate. Exploiting these distinctive characteristics and the independent expression of the receptors in some cells, we have been able to reevaluate the so-called cross-desensitization by analyzing the ability of GABA, glutamate, and other agonists to interact with each of the receptor molecules.
The cross-desensitization was found to be exclusively attributable to the ability of GABA to interact with the glutamate receptor (Oyama et al., 1990). The GABA receptor is unaffected by glutamate. Nevertheless, in cells expressing both receptors, glutamate can reduce the GABA response by auto-desensitizing the part of the response that is mediated by the glutamate receptor. No interactions were observed between ACh-induced responses and either of the responses elicited by the amino acids.

The invertebrate glutamate-gated $\mathrm{Cl}$ channels that have been cloned resemble the vertebrate glycine receptor (Vassilatis et al., 1997). Our pharmacological evaluation of the molluscan glutamate receptor points in the same direction.

Key words: GABA; glutamate; acetylcholine; cross-desensitization; chloride channel; Aplysia; mollusk; neuron; pharmacological characteristics; sulfate
A number of studies on vertebrate neurons have described interactions between inhibitory $\mathrm{Cl}$ responses elicited by GABA, glycine, and $\beta$-alanine, e.g., between responses to GABA and glycine (Barker and McBurney, 1979; Hamill et al., 1983; Baev et al., 1992; Lewis and Faber, 1993; Trombley et al., 1999), between responses to $\beta$-alanine and either GABA or glycine (Choquet and Korn, 1988 ), and between responses to glycine and $\beta$-alanine (Krishtal et al., 1988). The demonstration that recombinant homomeric glycine receptors (formed from subunits cloned from zebrafish) can be activated by GABA (Fucile et al., 1999) might well explain certain of the interactions observed in vertebrate neurons between GABAand glycine-induced responses.

In invertebrates, many different neurotransmitters, including glutamate but not glycine, gate $\mathrm{Cl}$ channels. In cells in which different transmitters activate $\mathrm{Cl}$ conductances, interactions observed between the responses have led to the suggestion that different transmitters share the same receptor molecule. For example, in crayfish muscle, a single $\mathrm{Cl}$ channel is activated by similar concentrations of glutamate, GABA, and acetylcholine (ACh) (Franke et al., 1986; Zufall et al., 1988). In certain identified Aplysia neurons, these same three transmitters often increase $\mathrm{Cl}$ conductance in the same cell, but studies evaluating interactions between these responses have yielded conflicting conclusions. King and Carpenter (1987) observed bi-directional "cross-desensitization" between the GABA and glutamate responses and suggested that, as in crayfish muscle, these two amino acids share the same receptor molecule. However, Ikemoto and Akaike (1988) failed to observe any interactions, and Oyama et al. (1990) observed that, whereas the glutamate response was diminished in the presence of GABA, only a

\footnotetext{
Received March 27, 2000; revised Aug. 31, 2000; accepted Sept. 11, 2000.

This research was supported by the Centre National de la Recherche Scientifique (Unité Mixte de Recherche 8544) (to J.K.) and by Université Pierre et Marie Curie Visiting Professorship and INTAS-93-3269 (to C.V.).

Correspondence should be addressed to JacSue Kehoe, Laboratoire de Neurobiologie, Ecole Normale Supérieure, 46, rue d’Ulm, Paris, 75005, France. E-mail: kehoe@wotan.ens.fr.

Copyright (C) 2000 Society for Neuroscience $0270-6474 / 00 / 208585-12 \$ 15.00 / 0$
}

distinctive slowly desensitizing, high-threshold element of the GABA response was diminished by glutamate. They proposed that this element of the GABA response was attributable to GABA activation of the glutamate receptor. In contrast, similar studies on other invertebrate ganglionic neurons revealed no interactions between GABA and glutamate Cl-dependent responses (lobster, Cleland and Selverston, 1998; crab, Duan and Cooke, 2000).

In the present study, we have reexamined the interactions between the glutamate-, GABA-, and ACh-activated responses in Aplysia neurons. By exploiting our finding that the GABA-gated channel has distinguishing characteristics and the fact that, in certain cells, only one of the relevant receptors is expressed, we have shown that all three of these transmitters open $\mathrm{Cl}$ channels by binding to distinct and independent molecular entities. Nevertheless, interactions were shown to exist between the GABA and glutamate responses. These seemingly bi-directional interactions can be entirely explained by the ability of GABA to interact with the glutamate receptor (Oyama et al., 1990).

\section{MATERIALS AND METHODS}

Experimental preparation. The experiments described in this paper were performed on cells from either the buccal, pleural, or cerebral ganglia of Aplysia.

The ganglia were prepared as described previously (Kehoe, 1985). For the study of the coexpressed GABA, glutamate, and ACh receptors mediating $\mathrm{Cl}$-dependent responses, two series of cells were used: the medial cells of the pleural ganglia (Kehoe, 1972b) and selected cells from the buccal ganglia (including B3 and B6) (Gardner and Kandel, 1977). For examining glutamate-induced $\mathrm{Cl}$-dependent responses in cells having no GABA receptor, we used small unpigmented cells from the pleural ganglia (Ascher et al., 1978), whereas, for the evaluation of GABA-induced $\mathrm{Cl}$-dependent responses in cells having no glutamate-induced $\mathrm{Cl}$ response, we chose small, unpigmented cells located on the base of the midline of the dorsal surface of the cerebral ganglion.

Electrodes, voltage clamp, recording procedures, and treatment of data. For experiments illustrated in Figures $2 A-C, 3 B, 4 B, 6 C$, and $10 A$, whole-cell patch-clamp methods (Hamill et al., 1981) were used (for details, see Kehoe, 1994). Pipettes of 200-500 k $\Omega$ ensured a good exchange, and data were retained only from cells for which the access resistance remained constant throughout the experiment. In all other experiments, recordings were made in conventional microelectrode voltage clamp using handpulled microelectrodes made with a de Fonbrune microforge and filled 
with $0.5 \mathrm{M} \mathrm{K}_{2} \mathrm{SO}_{4}$. Although cells with intact axons were used in these experiments, and obviously the voltage in much of the axon was not controlled by the somatically placed electrodes, clamp error cannot explain the changes in response amplitude studied in these experiments. No evidence of a failure to control somatic voltage was seen in the voltage traces, and the control of the somatic voltage was evident from the unchanging amplitude of one of the two agonist-induced responses in experiments in which the other agonist response was markedly reduced. Activation of axonal membrane was minimized by the somatic application of the agonist and by its rapid removal by the flow from the control tube, as well as by a continual superfusion of the entire ganglion. For an additional description of the characteristics of the two-electrode voltage clamp, see Kehoe (1985).

Continuous recordings were made on a Servogor 340 paper recorder and on a digital audio tape recorder. Records of currents elicited by agonis applications were digitized and sampled on-line on a Dell (Round Rock, TX) computer, via a Cambridge Electronic Design (Cambridge, UK) 1401 interface, using the Whole Cell Eectrophysiology program from Strathclyde Electrophysiological Software.

External and internal solutions. The artificial seawater (ASW) bathing the ganglion contained (in $\mathrm{mM}$ ): $480 \mathrm{NaCl}, 10 \mathrm{KCl}, 10 \mathrm{CaCl}_{2}, 50 \mathrm{MgCl}_{2}$, and $10 \mathrm{Na}-\mathrm{HEPES}, \mathrm{pH}$ 7.8. The internal solution used in the whole-cell clamp experiments illustrated here contained (in $\mathrm{mM}$ ): $411 \mathrm{~K}_{2} \mathrm{SO}_{4}, 8.3$ $\mathrm{Na}_{2} \mathrm{SO}_{4}, 1 \mathrm{CaCl}_{2}, 2 \mathrm{MgCl}_{2}$, and 1.5 EGTA, buffered with $20 \mathrm{~K}$-HEPES to $\mathrm{pH}$ 7.4. In a few nonillustrated experiments, a KCl-based solution was used to show that the relevant factor causing the diminution of the GABA response in whole-cell perfusion experiments came from the presence of sulfate ions in the internal solution. The KCl-based internal solution contained (in mM): $496 \mathrm{KCl}, 10 \mathrm{NaCl}, 2 \mathrm{MgCl}_{2}, 1 \mathrm{CaCl}_{2}, 1.5 \mathrm{EGTA}$, and 20 K-HEPES, pH 7.4.

Fast application system. The fast application system used here has been described previously in detail (Johnson and Ascher, 1987; Kehoe, 1994). Three glass tubes held together with heat-shrink tubing were moved laterally so that the appropriate (ASW or agonist-containing) tube was directly in front of the cell being studied. The central tube, called the "control tube," contained ASW that continually bathed the cell under study except when the tubes were moved laterally to permit a 2 sec application of one of the agonists. Solenoid-driven valves were placed in the line of the tubing feeding each of the agonist-containing glass tubes, permitting the flow of agonist only when the relevant tube was directly facing the cell. Although the concentration jump occurring at the tip of the tubes is very rapid, the relevant measurement is of course the speed at which the solutions flowing from the tube envelop the cell. An estimation of this exchange was made by switching from normal ASW in the control tube (containing $10 \mathrm{~mm} \mathrm{~K}$ ) to high-K seawater (containing $154 \mathrm{~mm} \mathrm{~K}$ ). The time to reach $67 \%$ of the maximal current induced by the high-K seawater was found to be on the order of $70-80 \mathrm{msec}$.

The duration of agonist application in all experiments was $2 \mathrm{sec}$, and the interval between applications was $1 \mathrm{~min}$. Because in most experiments there was an alternation between two different agonists (e.g., GABA and glutamate), for a given agonist, a 2 min interval separated two successive applications. With the agonist concentrations used here, this regimen yielded control responses of a constant amplitude. The antagonists were applied only through the control tube (see exception in Fig. 9A). This implies that, during the $2 \mathrm{sec}$ application of the agonist, a partial wash of the preapplied antagonist occurs. The application of desensitizing agonists through the control tube resulted in a similar partial wash during the $2 \mathrm{sec}$ agonist application. This led, at some concentrations, to particularities in the recorded currents that are discussed in the relevant text describing the figures.

Drugs. GABA, L-glutamic acid (monosodium salt), ACh, $\beta$-alanine, tubocurarine chloride (TC), strychnine hydrochloride, and pentobarbital were all obtained from Sigma (St. Louis, MO); methyllycaconitine citrate (MLA) was obtained from Research Biochemicals (Natick, MA); and cis-4-aminocrotonic acid (CACA), trans-4-aminocrotonic acid (TACA) hypotaurine, and bicuculline methochloride were obtained from Tocris Cookson (Bristol, UK).

Experimental $\mathrm{n}$ values, statistical analyses, and experimental controls. Each conclusion that has been illustrated in this paper was drawn from a minimum of three experiments (with the exception of that illustrated in Fig. $2 B$, for which only two experiments were performed). Statistical analyses using either the ANOVA test (Figs. $1 C, 8$ ) or the Student's $t$ test (other figures) quantified the effects of the various manipulations on the responses to the different agonists.

\section{RESULTS \\ Comparison of glutamate- and GABA-gated Cl responses}

Glutamate, GABA, and ACh each elicits a rapidly activated inhibitory response in a number of neurons in Aplysia central ganglia. In a given experiment and at a given time, the reversal potential of this response is the same for all three of the transmitters and has been shown, for the response to $\mathrm{ACh}$, to be equal to the $\mathrm{Cl}$ equilibrium potential (Kehoe, 1972a). Such cells offer an easily controlled comparison of these receptor-operated channels and provide a good preparation for the evaluation of any possible interactions between them. In this paper, only the glutamate and GABA responses will be described in detail, but some data will be presented concerning the $\mathrm{ACh}$-induced $\mathrm{Cl}$-dependent responses (Kehoe and McIntosh, 1998) that coexist with the glutamate and GABA Cl responses in the medial cells of the pleural ganglia, as well as in selected cells of the buccal ganglia (e.g., B3 and B6) (Gardner and Kandel, 1977).

A given molluscan neuron often expresses more than one receptor type for a given transmitter. That is the case for glutamate in the medial cells studied here, because, in addition to gating a $\mathrm{Cl}$ channel in those cells, glutamate also activates a nonspecific cationic channel, thereby eliciting a two-component response (King and Carpenter, 1987). Because the cationic response desensitizes very rapidly, it does not interfere with the peak of the glutamateactivated increase in $\mathrm{Cl}$ conductance and has consequently not been pharmacologically eliminated for these experiments.

\section{Differential voltage dependence of the glutamate- and $G A B A$ - gated $\mathrm{Cl}$ conductances}

Examples of the responses to glutamate and GABA in the two different cell types are shown in Figure 1. In the medial cells (Fig. $1 A$ ), it can be seen that the $\mathrm{Cl}$ current elicited by glutamate (outward at $-26 \mathrm{mV}$, inward at $-66 \mathrm{mV}$, with the reversal potential in this cell at $-46 \mathrm{mV}$ ) is preceded by a very rapidly desensitizing cationic inward current. The only response elicited by GABA in the same cells is a Cl-dependent one, hence no change in current is seen at $\mathrm{E}_{\mathrm{Cl}}(-46 \mathrm{mV})$. Figure $1 B$ illustrates records from one of the selected buccal cells in which both glutamate and GABA activate only $\mathrm{Cl}$-dependent responses. (Given the rapidity of the desensitization of the glutamate cationic response, such a response might be missed in these large cells, which are often a few hundred micrometers in diameter. For cells of this size, the fast application tubes must be pulled back further from the cell surface, and the speed of the concentration jump at the level of the membrane is thereby reduced.)

An examination of the outward- and inward-going responses to the two amino acids reveals that, when the holding potential is fixed on either side of (but equidistant from) $\mathrm{E}_{\mathrm{Cl}}$, the inward and outward currents elicited by glutamate are of equal amplitude, whereas the inward current elicited by GABA is always smaller than the outward current. This was shown to be true in both cell types. In Figure $1, A$ and $B$, the response recorded at a holding potential more negative than $\mathrm{E}_{\mathrm{Cl}}$ has been multiplied by -1 and is represented by a dashed line to permit an easy comparison with the amplitude of the outward current. The vertical dashed line crossing the recordings indicates the end of the agonist application and the return to ASW flowing from the control tube.

A statistical evaluation of the differential voltage dependence of the GABA- and glutamate-induced conductances is presented in Figure $1 C$, and the results obtained from an ANOVA of these data are presented in the legend to Figure 1. The outward rectification of the GABA-induced conductance has been described previously (Matsumoto, 1982; King and Carpenter, 1987, 1989).

\section{Differential effect of intracellular sulfate ions on the glutamate and $G A B A$ responses}

The differential voltage dependence of the $\mathrm{Cl}$ conductances activated by glutamate and GABA suggests that the two transmitters gate different types of $\mathrm{Cl}$ channels.

This impression was reinforced by the differential effect of intracellular sulfate ions observed here on the responses to GABA and glutamate. The experiments illustrated in Figure $2 A-C$ were performed in whole-cell patch-clamp mode, so the solution in the pipette was constantly exchanging with the cytoplasm, hence altering the internal $\mathrm{Cl}$ concentration and thereby provoking changes in $\mathrm{E}_{\mathrm{Cl}}$. Consequently, in Figure 2, $A$ and $B$, periodic adjustments throughout the experiments were made to ensure that the holding potential remained at a constant distance from $\mathrm{E}_{\mathrm{Cl}}$. Under these 
A

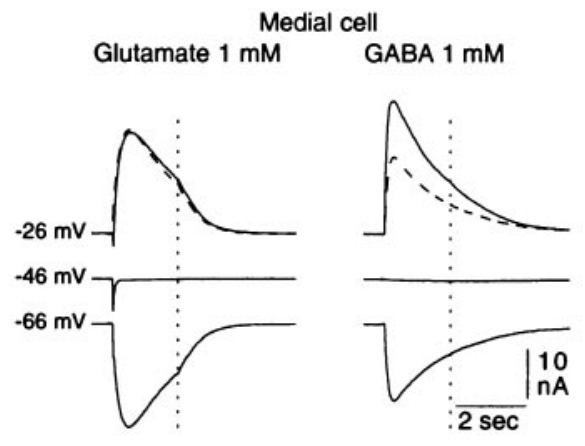

B

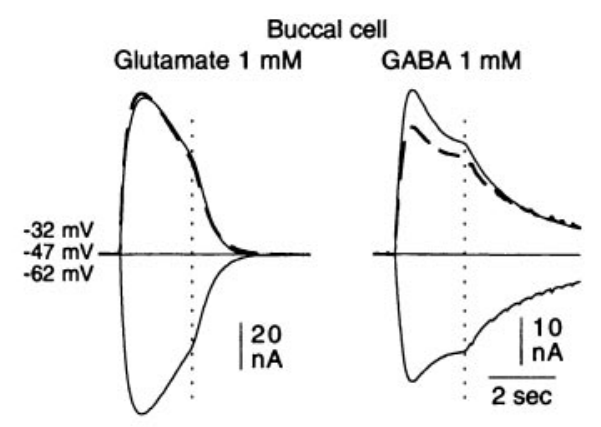

Figure 1. Differential voltage dependence of glutamate- and GABA-activated $\mathrm{Cl}$ conductances measured in two-electrode voltage clamp in medial and buccal cells. $A$, Glutamate and GABA responses in a medial cell. Glutamate elicited a two-component response consisting of a rapidly desensitizing cationic element (seen here as an inward current at all holding potentials) and an inhibitory, Cldependent element that is manifested by an outward current at $-26 \mathrm{mV}$, an inward current at $-66 \mathrm{mV}$, and 0 net current at $\mathrm{E}_{\mathrm{Cl}}(-46$ $\mathrm{mV})$. The inward and outward $\mathrm{Cl}$ currents, measured at holding potentials $20 \mathrm{mV}$ on either side of $\mathrm{E}_{\mathrm{Cl}}$, were of equal amplitude. The dashed line represents the inward current multiplied by -1 for easier comparison with the outward current measured at $-26 \mathrm{mV}$. GABA elicited a pure Cl-dependent response in the medial cells, so 0 net current is recorded at $\mathrm{E}_{\mathrm{Cl}}$. Again, the dashed line represents the inward GABA-induced current multiplied by -1 . It can be seen that the GABA response measured at a holding potential 20 $\mathrm{mV}$ more negative than $\mathrm{E}_{\mathrm{Cl}}$ is much smaller than that measured $20 \mathrm{mV}$ less negative than $\mathrm{E}_{\mathrm{Cl}}$. The vertical dashed line indicates the end of the $2 \mathrm{sec}$ agonist application and the return to the flow of ASW over the cell. $B$, Glutamate and GABA responses in a buccal neuron. Note that no cationic response to glutamate can be detected in this cell. Here the $\mathrm{Cl}$ currents were measured at holding potentials $15 \mathrm{mV}$ on either side of $\mathrm{E}_{\mathrm{Cl}}$. As was the case for the medial cell, the glutamate-activated conductance in the buccal cell showed no voltage dependence, whereas that induced by GABA showed outward rectification. $C$, It can be seen that the mean percent of inverted to noninverted responses is clearly different for the GABA and glutamate responses and that, for the GABA response, there is an evident difference in the same measurement as a function of voltage. This impression was verified by an ANOVA that reveals that the probability under the null hypothesis of the

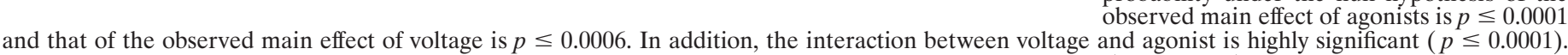
In contrast, the differences observed between cell types do not permit the rejection of the null hypothesis $(p=0.2025)$.

conditions, the amplitude of the glutamate response remained constant (mean of six experiments was $99.1 \%$ of control; $\sigma=$ $2.13 \%$ ), whereas that to GABA decreased progressively to an average of $37.7 \%$ of the control value $(\sigma=8.33 \%)$ after $\sim 20 \mathrm{~min}$ whole-cell perfusion $(n=6 ; p \leq 0.0001)$. Figure $2 B$ shows that the blocking effect of sulfate on the GABA response is completely independent of both membrane voltage and the direction of current flow. In this experiment made at $\pm 15 \mathrm{mV}$ on either side of $\mathrm{E}_{\mathrm{Cl}}$, the inward/outward current ratio was maintained at $68 \%$, despite a sulfate-induced reduction in the GABA response amplitude to $36 \%$ of the initial value. In the second such experiment (data not shown) performed at $\pm 10 \mathrm{mV}$ on either side of $\mathrm{E}_{\mathrm{Cl}}$, the inward/ outward current ratio was maintained at $78 \%$ throughout the sulfate-induced diminution of the absolute response amplitude, which reached $57 \%$ of the initial amplitude after $20 \mathrm{~min}$ whole-cell recording.

Figure $2 C$ illustrates another protocol for studying the differential effect of internal sulfate ions on the GABA and glutamate responses. In this experiment, the holding potential was held constant while $\mathrm{E}_{\mathrm{Cl}}$ became more negative because of the whole-cell perfusion. Because of the resulting increase in driving force for $\mathrm{Cl}$ ions, the response to glutamate increased, whereas, despite the change in driving force, the response to GABA decreased. This simplified protocol, which of course leads to the same conclusion, was used in experiments to be described later evaluating differential effects of intracellular sulfate on responses elicited by various agonists.

It is known that GABA responses in some mammalian neurons show rundown when intracellular ATP is washed out by whole-cell perfusion (Shirasaki et al., 1992). This however was not the explanation for the observation made here, because the results were unchanged by the inclusion of ATP and GTP in the $\mathrm{K}_{2} \mathrm{SO}_{4}$-based internal solution. Furthermore, when KCl-based, ATP-free solutions were used (three experiments), GABA and glutamate responses changed proportionately as intracellular perfusion progressed (data not shown). Finally, the same differential blockade of the GABA response by sulfate ions was seen (Fig. $2 D$ ) when $0.5 \mathrm{M}$ $\mathrm{K}_{2} \mathrm{SO}_{4}$ was simply injected by pressure into a cell in which recordings were made with conventional two-electrode voltage clamp, thereby avoiding any possibility of washout associated with wholecell perfusion (see figure legend for a statistical résumé of the relevant experiments).

\section{Pharmacological distinctions between the glutamate and $\mathrm{GABA}$ responses}

One of the factors that has held back the identification of glutamatergic and GABAergic synapses in molluscan nervous systems is the paucity of pharmacological tools that have been found to be selective for the different $\mathrm{Cl}$-dependent responses activated by these different transmitters. In an effort to distinguish further between the glutamate- and GABA-induced $\mathrm{Cl}$ responses and to provide compounds that could eventually assist in identifying synapses using these neurotransmitters, a number of potential agonists and antagonists were evaluated.

\section{$\beta$-alanine}

$\beta$-alanine (1 mM) was found to elicit in both the medial and buccal cells a $\mathrm{Cl}$-dependent response that reflects the activation of the 
Figure 2. Selective blockade by sulfate ions of the GABA-induced Cldependent response. $A$, Whole-cell recording with $\mathrm{K}_{2} \mathrm{SO}_{4}$-based internal solution in a buccal cell. The membrane potential was maintained at 15 $\mathrm{mV}$ less negative than $\mathrm{E}_{\mathrm{Cl}}$. Whole-cell perfusion with a sulfate-containing internal solution caused a selective diminution of the GABA-induced Cldependent response. From six experiments in which the effect of sulfate was measured $20 \mathrm{~min}$ after control responses, the glutamate response was maintained at $99.1 \%$ of control $(\sigma=$ $2.13 \%$ ), whereas that to GABA decreased to $37.7 \%$ control $(\sigma=8.33 \%$; $p \leq 0.00002)$. B, A similar experiment on a medial cell response to GABA illustrated at $\pm 15 \mathrm{mV}$ on either side of $\mathrm{E}_{\mathrm{Cl}}$. It can be seen that the reduction of the GABA response induced by a 20 min whole-cell recording with an intracellular sulfate-based solution is independent of membrane voltage and of the direction of current flow, with inward current being $68 \%$ of the outward current before and after reduction of the response by sulfate to $36 \%$ of the control value (see Results for additional data). $C$, Whole-cell recording with $\mathrm{K}_{2} \mathrm{SO}_{4}$-based internal solution of a medial cell response to $1 \mathrm{~mm}$ glutamate and $1 \mathrm{~mm}$ GABA. Holding potential was maintained at $-30 \mathrm{mV}$, and $\mathrm{E}_{\mathrm{Cl}}$ shifted to more negative values as the internal solution entered the cell. The increased driving force on $\mathrm{Cl}$ ions caused an increase in the glutamate response, but the blocking effect of sulfate ions counteracted and dominated the facilitory effect of an increased driving force on the GABA response. $D$, Two-electrode voltage-clamp recording of glutamate and GABA responses from a medial cell held at -30

A

Block of GABA response by intracellular sulphate (cell held at $15 \mathrm{mV}$ less negative than $\mathrm{E}_{\mathrm{Cl}}$ )

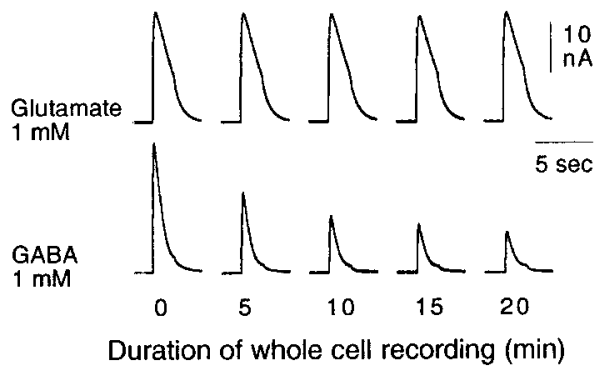

C

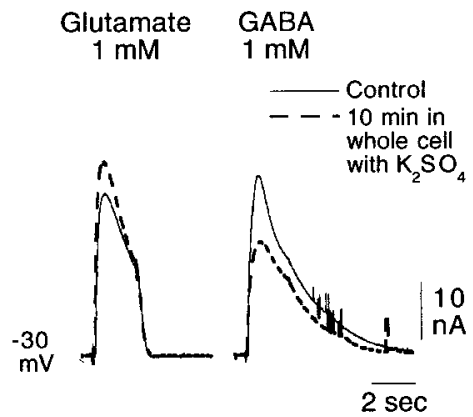

Block of GABA response by intracellular sulphate occurs on both sides of $E_{\mathrm{Cl}}( \pm 15 \mathrm{mV})$.

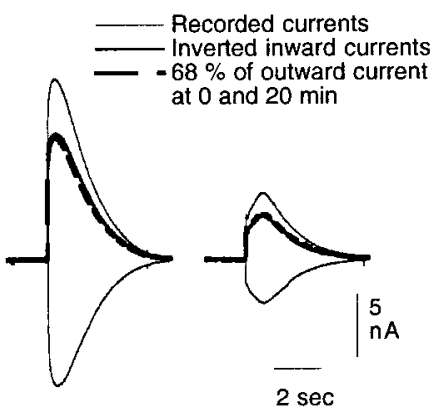

D

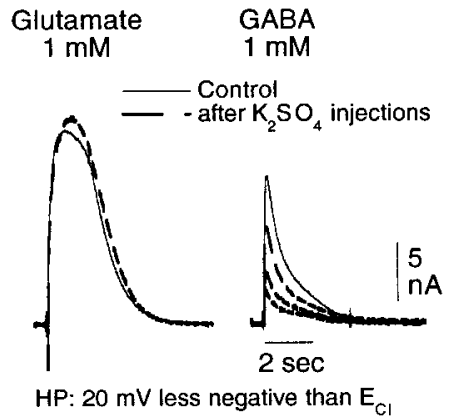

$\mathrm{mV}$. From a third microelectrode introduced into the cell, three brief pressure injections of $0.5 \mathrm{M} \mathrm{K}_{2} \mathrm{SO}_{4}$ were made. These three injections caused the selective and progressive decline in the amplitude of the GABA-induced Cl-dependent response. From three such experiments, the average GABA response measured at 13-15 min after the first injection was $26 \%$ of the control amplitude $(\sigma=5.57 \%)$, whereas the average glutamate response was $102.6 \%$ of control $(\sigma=4.16 \% ; p \leq 0.00004)$.

glutamate rather than of the GABA receptor. The response to $\beta$-alanine was, on average, $45 \%$ of the peak amplitude of the response to $1 \mathrm{~mm}$ glutamate in the same cells $(n=5 ; \sigma=5.59 \%)$. Like the glutamate-activated conductance, that activated by $\beta$-alanine showed no voltage dependence (Fig. $3 A$ ). Furthermore, the response to $\beta$-alanine, like the glutamate response, was not blocked by intracellular sulfate. In a cell held at $-30 \mathrm{mV}$ (Fig. $3 B$ ), the increase in outward-going currents in response to both glutamate and $\beta$-alanine as whole-cell perfusion proceeds reflects the perfusion-induced change in $\mathrm{E}_{\mathrm{Cl}}$. The two responses show the same percent increase. The mean difference in increases for the two responses in such experiments was, for $n=3,1 \%(\sigma=0.8 \%)$. Another manifestation of the fact that $\beta$-alanine activates the glutamate receptor preferentially can be seen in Figure $3 C$ in which $50 \mu \mathrm{M} \beta$-alanine is shown to selectively desensitize-block the glutamate Cl-dependent response (for $n=5$, mean glutamate response in $\beta$-alanine was $8 \%$ of control with $\sigma=3.67 \%$; mean GABA response in $\beta$-alanine was $81.8 \%$ of control with $\sigma=8.93 \%$; $p \leq 0.0002)$. This selectivity of $\beta$-alanine is not maintained at higher concentrations (see below) (Ikemoto et al., 1988a).

$\beta$-alanine is primarily known for its preferential action on vertebrate glycine receptors (Wu et al., 1993; Jonas et al., 1998). No glycine-induced $\mathrm{Cl}$-dependent responses have as yet been reported in invertebrate neurons, and even at $10 \mathrm{~mm}$, glycine failed to increase $\mathrm{Cl}$ conductance in any of the cell types used in this study (three experiments for each cell type; data not shown).

In addition to activating a $\mathrm{Cl}$ conductance, glutamate has been shown to act on two other pharmacologically and ionically distinct receptors: one mediating a cationic excitatory response (see the rapid inward current in the medial cells) (Kehoe, 1978; King and Carpenter, 1987), and the other, a K-dependent inhibitory response (Kehoe, 1978, 1994; Katz and Levitan, 1993). $\beta$-alanine neither activated nor blocked the glutamate receptors mediating these two responses (results from three experiments studying each of the two other glutamate receptors).

\section{$T A C A$}

The GABA analog TACA activates a conductance that, like that activated by GABA, is voltage-dependent (Fig. $4 A$ ) and is blocked by intracellular sulfate ions (Fig. $4 B$ ). Furthermore, TACA (100 $\mu \mathrm{M})$ preferentially desensitizes-blocks the GABA response (Fig. $4 C$ ) (Fig. 4A-C, see legend for statistical analyses of the findings illustrated).

\section{Hypotaurine}

Hypotaurine, an endogenous amino acid shown to have inhibitory effects in cerebellar slices (Okamoto and Sakai, 1981), had no agonist effect on any of the cells tested. However, it did preferentially block the $\mathrm{Cl}$-dependent response to glutamate, having only a very slight effect on the Cl-dependent response to GABA (Fig. 5A, see legend for statistical evaluation of relevant experiments). Hypotaurine had no blocking effect on either the cationic or the K-dependent glutamate response (three experiments on each response type; data not shown).

\section{$C A C A$}

CACA, an agonist of $\mathrm{GABA}_{\mathrm{C}}$ vertebrate receptors (Johnston, 1996), induced only a weak current in the cells studied here, but, 

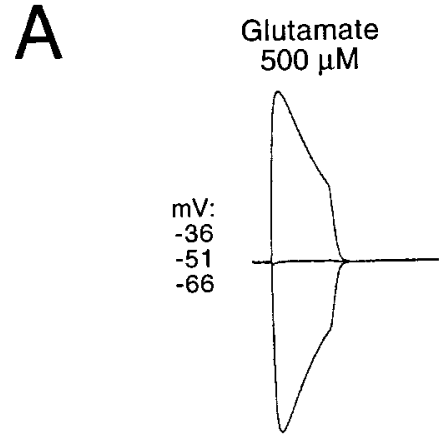

$\beta$-alanine
$500 \mu \mathrm{M}$
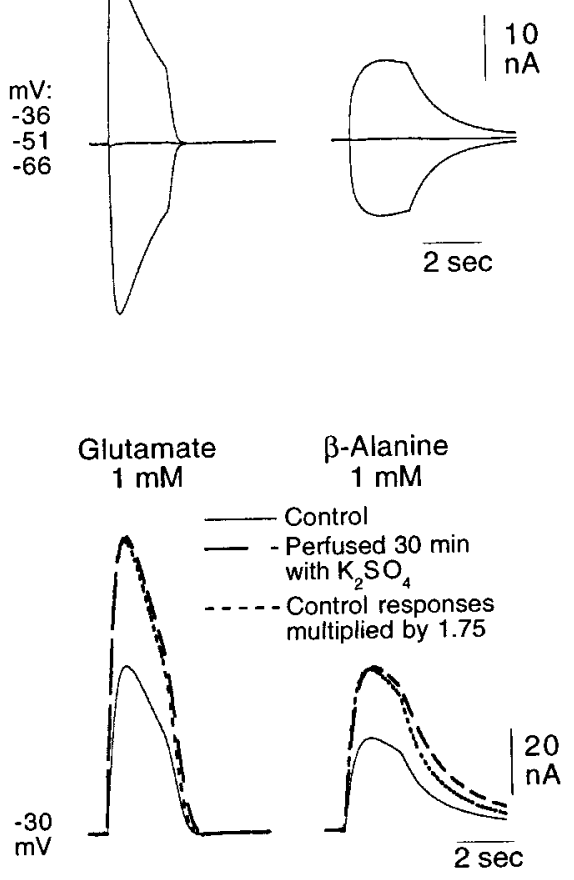

C

Glutamate $1 \mathrm{mM}$

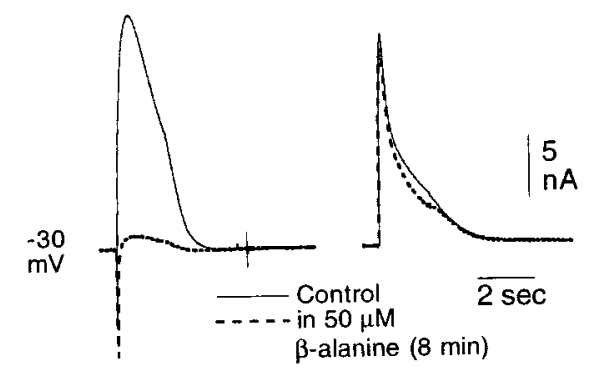

Figure 3. $\beta$-alanine selectively activates the glutamate receptor in the buccal and medial cells. $A$, Responses of a buccal cell to glutamate and $\beta$-alanine were measured at $15 \mathrm{mV}$ either side of $\mathrm{E}_{\mathrm{Cl}}$ using a two-electrode voltage clamp. Note that the $\beta$-alanine-induced inward and outward currents measured at $15 \mathrm{mV}$ on either side of $\mathrm{E}_{\mathrm{Cl}}$, like those to glutamate, are of equal amplitude (mean inward to outward current for glutamate was $99.3 \%$ with $\sigma=1.15 \%$; that for $\beta$-alanine was $100 \%$ with $\sigma=2.52 \%$; $p=$ 0.56 ). $B$, Whole-cell recording with a $\mathrm{K}_{2} \mathrm{SO}_{4}$-based internal solution of responses to glutamate and $\beta$-alanine in a buccal cell held at $-30 \mathrm{mV}$. Note that the glutamate- and $\beta$-alanine-induced responses increased proportionately as $\mathrm{E}_{\mathrm{Cl}}$ changed over time with whole-cell perfusion using the sulfatebased solution (mean difference between changes in the glutamate and $\beta$-alanine responses in sulfate was $1 \% ; \sigma=0.8 \%$ ). $C$, Two-electrode voltage-clamp recordings of glutamate and GABA responses from a medial cell held at $-30 \mathrm{mV}$. $\beta$-alanine $(50 \mu \mathrm{M})$ applied through the control tube induced no change in holding current but selectively desensitized-blocked the response to glutamate (for $n=5$, mean glutamate response in $\beta$-alanine was $8 \%$ of control with $\sigma=3.67 \%$; mean GABA response in $\beta$-alanine was $81.8 \%$ of control with $\sigma=8.93 \% ; p \leq 0.0002)$.

like TACA, preferentially desensitized-blocked the GABA Cldependent response, having only a very weak blocking effect on the glutamate response (Fig. 5B, see legend for statistical analysis of three experiments of this type).

A number of other compounds (TC, strychnine, bicuculline, and pentobarbital) were tested at $100 \mu \mathrm{M}$ on the glutamate- and GABA-induced Cl-dependent responses (data not shown). TC
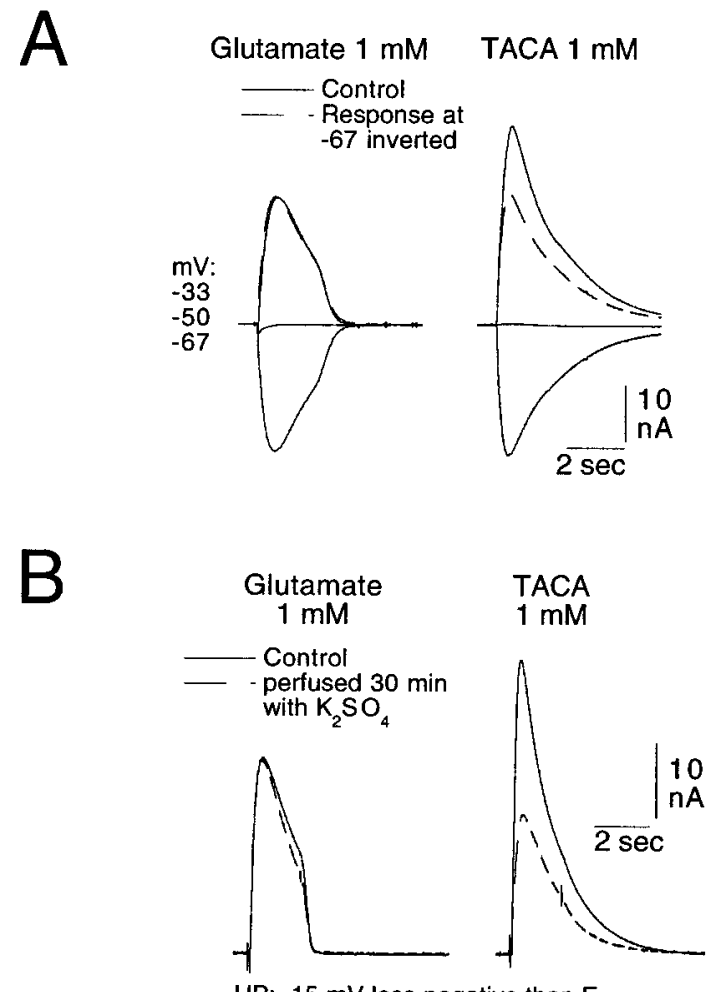

HP: $15 \mathrm{mV}$ less negative than $\mathrm{E}_{\mathrm{Cl}}$

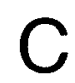

Glutamate $1 \mathrm{mM}$

GABA $1 \mathrm{mM}$

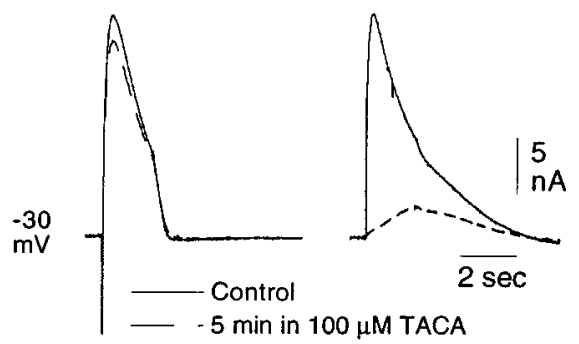

Figure 4. TACA selectively activates the GABA receptor in the buccal and medial cells. $A$, Responses of a buccal cell to glutamate and TACA measured with a two-electrode voltage clamp at $17 \mathrm{mV}$ on either side of $\mathrm{E}_{\mathrm{Cl}}$. Note that the amplitude of the TACA-induced currents measured at 17 $\mathrm{mV}$ on either side of $\mathrm{E}_{\mathrm{Cl}}$ are not of equal amplitude, with the TACAinduced inward current being smaller than the TACA-induced outward current. The inward and outward currents elicited by glutamate at the same holding potentials are of equal amplitude (mean inward to outward current for glutamate was $102 \%$ with $\sigma=2.39 \%$; that for TACA was $59.2 \%$ with $\sigma=6.06 \% ; n=5 ; p \leq 0.0001)$. $B$, Whole-cell recording with a $\mathrm{K}_{2} \mathrm{SO}_{4}$-based internal solution of responses to glutamate and TACA of a buccal cell held at $15 \mathrm{mV}$ less negative than $\mathrm{E}_{\mathrm{Cl}}$. Note that there is a selective diminution in the TACA-induced response. Pooling data from experiments using the protocol illustrated in $B$ with experiments in which the holding potential was held constant, it was found that sulfate caused a mean relative diminution in the TACA response to $37.5 \%(\sigma=9.76 \% ; n=3)$. $C$, Twoelectrode voltage-clamp recordings of glutamate and GABA responses from a medial cell held at $-30 \mathrm{mV}$. TACA $(100 \mu \mathrm{M})$ applied through the control tube induced no change in holding current but selectively desensitized-blocked the response to GABA. A quantitative evaluation of this reduction was made by measuring the response in TACA at the time corresponding to the peak control response, because the TACA block was rapidly reduced during the $2 \mathrm{sec}$ application of agonist solutions, which contained no TACA. Such an analysis of five experiments yielded a mean reduction in the glutamate response to $78 \%$ of the control $(\sigma=10.7 \%)$ and a mean reduction in the GABA response to $7.3 \%$ of the control $(\sigma=7.9 \%)$, with $p \leq 0.0002$. 
A

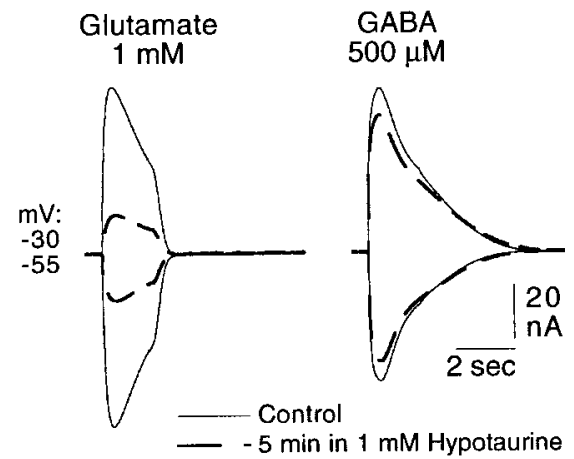

B

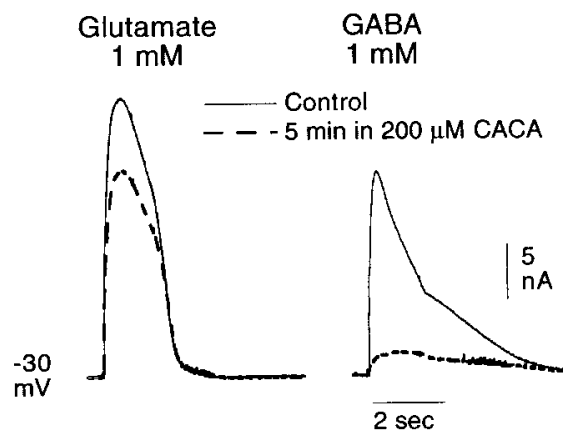

Figure 5. Preferential block of the glutamate $\mathrm{Cl}$-dependent response by hypotaurine and preferential block-desensitization of the GABA CIdependent response by CACA. $A$, Effect of $1 \mathrm{~mm}$ hypotaurine on equal amplitude responses of a medial cell to $1 \mathrm{~mm}$ glutamate and $500 \mu \mathrm{M}$ GABA measured in two-electrode voltage clamp at $17 \mathrm{mV}$ on either side of $\mathrm{E}_{\mathrm{Cl}}$. Note that hypotaurine, which induced no change in holding potential, preferentially blocked the glutamate-induced response. The glutamate response was reduced to $20.2 \%(\sigma=6.33 \%)$ of the control, whereas that to GABA was only reduced to $87.7 \%(\sigma=12.6 \%)$ of the control $(n=3 ; p \leq$ 0.001). $B$, Effect of CACA on glutamate and GABA responses of a buccal cell measured in two-electrode voltage clamp at $-30 \mathrm{mV}$. CACA $(200 \mu \mathrm{M})$ applied through the control tube induced no change in holding current but preferentially desensitized-blocked the response to GABA. The GABA response was reduced to $13.7 \%(\sigma=4.04 \%)$ of the control, whereas that to glutamate was only reduced to $82.3 \%(\sigma=8.02 \%)$ of control $(n=3 ; p \leq$ 0.0002).

and strychnine were without effect on GABA responses but caused a small reduction in the glutamate response. The glutamate response in $100 \mu \mathrm{M}$ strychnine was reduced to an average of $86 \%$ of the control value $(n=3 ; \sigma=2 \%)$. Bicuculline caused a slight diminution in both the glutamate and GABA responses, whereas pentobarbital reduced the GABA response (Ikemoto et al., 1988a) to $\sim 20-30 \%$ of the control amplitude (three experiments) but had practically no effect on the glutamate response. Even with 1 and 10 $\mu \mathrm{M}$ concentrations, the effect of pentobarbital was to reduce rather than potentiate the GABA response.

\section{Differential expression of GABA and glutamate receptors in different cells}

Cells in which the glutamate but not the GABA receptor is expressed reveal that $G A B A$ can activate the glutamate receptor

In a group of small identifiable cells in the right pleural ganglion (Ascher et al., 1978) in which glutamate activates a marked Cldependent response, GABA was shown to elicit a very weak response (Fig. 6A) that does not share the characteristics of the GABA responses seen in the medial or buccal cells. The GABAactivated $\mathrm{Cl}$ conductance in the small pleural cells was shown to be independent of voltage (Fig. $6 B$, response to $10 \mathrm{~mm}$ GABA) and unaffected by intracellular sulfate ions (Fig. 6C). Furthermore, like the response to glutamate in all of the cells studied, it was markedly
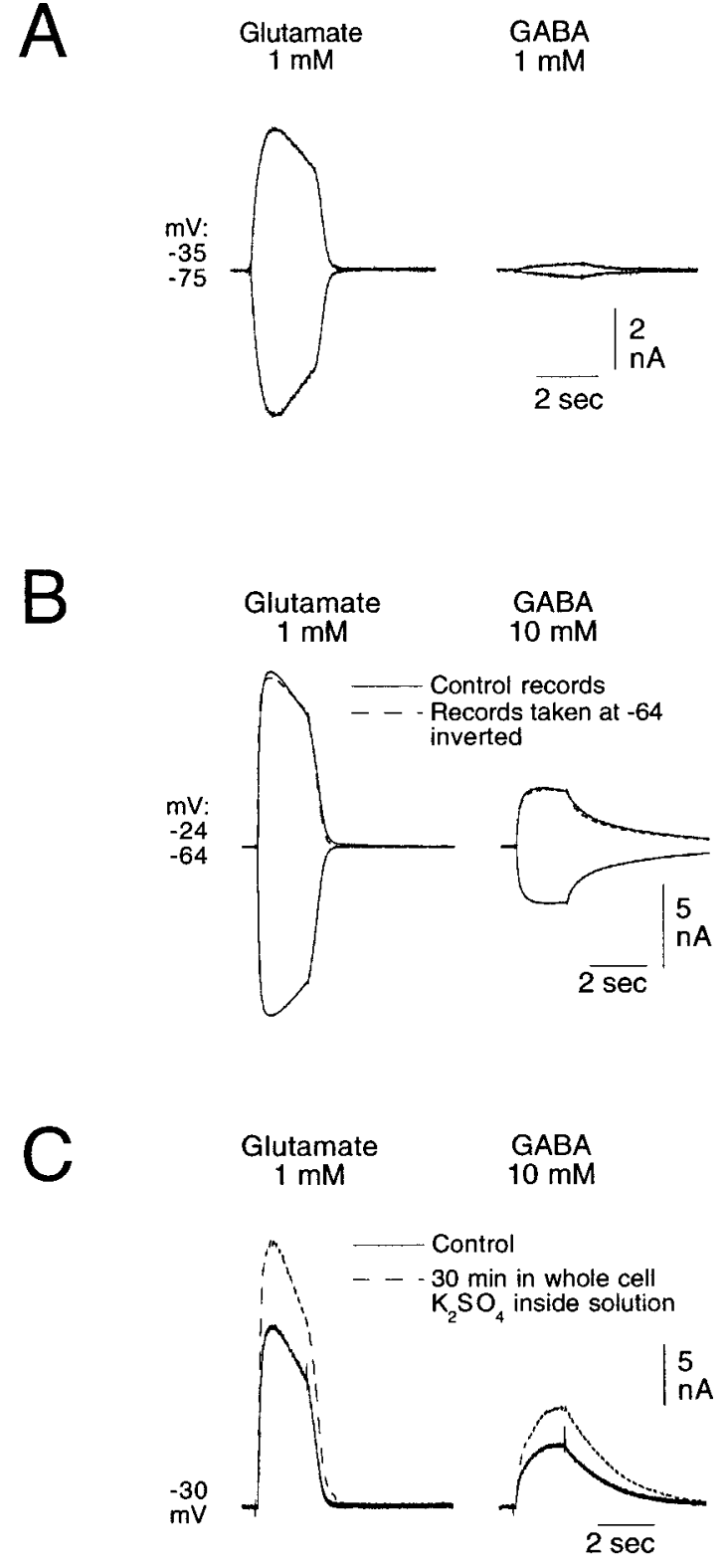

Figure 6. Recordings of glutamate and GABA responses in cells from an identifiable group situated near the pleural-pedal connective in the right pleural ganglion (Ascher et al., 1978). A, Responses to $1 \mathrm{~mm}$ glutamate and $1 \mathrm{mM}$ GABA recorded in two-electrode voltage clamp $20 \mathrm{mV}$ on either side of $\mathrm{E}_{\mathrm{Cl}}$. The response to $1 \mathrm{mM}$ GABA in these cells is only $3.83 \%$ of that to glutamate $(n=3 ; \sigma=0.289 \%)$. The glutamate-activated conductance in these cells, as in the buccal and medial cells, showed no voltage dependence. $B$, Using a $10 \mathrm{~mm}$ concentration of GABA, the response became large enough to compare it with the response to $1 \mathrm{~mm}$ glutamate recorded, again, in a small pleural cell. It can be seen that, in these cells, both glutamate and GABA elicited $\mathrm{Cl}$ conductances that are independent of voltage over the range tested. The mean percent of inward to outward current $(n=3)$ for the glutamate response was 100 , with $\sigma=1.89 \%$; that for GABA was 99.7, with $\sigma=0.57 \%(p=0.684)$. $C$, Recordings, made with whole-cell voltage clamp using a $\mathrm{K}_{2} \mathrm{SO}_{4}$-based internal solution, of the responses to $1 \mathrm{~mm}$ glutamate and $10 \mathrm{~mm}$ GABA in a small pleural cell held at $-30 \mathrm{mV}$. The GABA-induced response in these cells behaved like the glutamate-induced response, i.e., both increased as intracellular perfusion with the $\mathrm{K}_{2} \mathrm{SO}_{4}$-based solution progresses and $\mathrm{E}_{\mathrm{Cl}}$ becomes more negative. The effects of internal sulfate on the response to $1 \mathrm{~mm}$ glutamate and on the response to $10 \mathrm{~mm}$ GABA in these cells did not differ (mean glutamate response change was $172 \%$ with $\sigma=24.1 \%$; mean GABA response change was $172 \%$ with $\sigma=21.7 \% ; n=3 ; p=0.973$ ).

reduced by $50 \mu \mathrm{M} \beta$-alanine (Fig. $7 A$ ), weakly blocked by $100 \mu \mathrm{M}$ TACA (Fig. 7B), markedly reduced by $1 \mathrm{~mm}$ hypotaurine (Fig. $7 C$ ), and only slightly affected by $200 \mu \mathrm{M}$ CACA (Fig. $7 D$ ). In all of these respects, the current elicited by GABA in these cells resembles the 
A

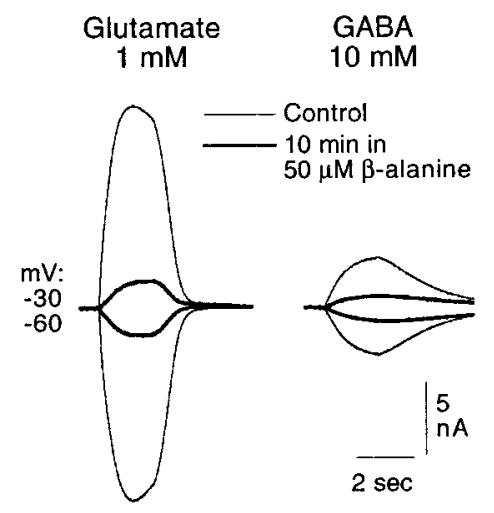

C

\section{$\underset{1 \mathrm{mM}}{\text { Glutamate }}$}

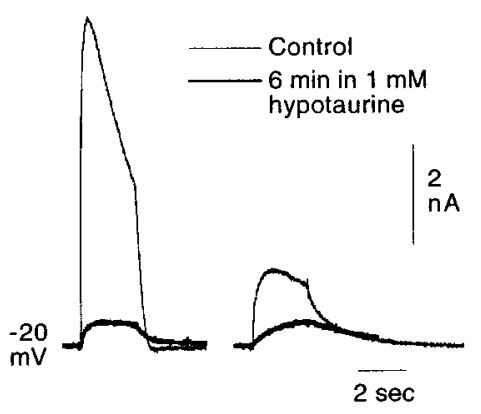

B
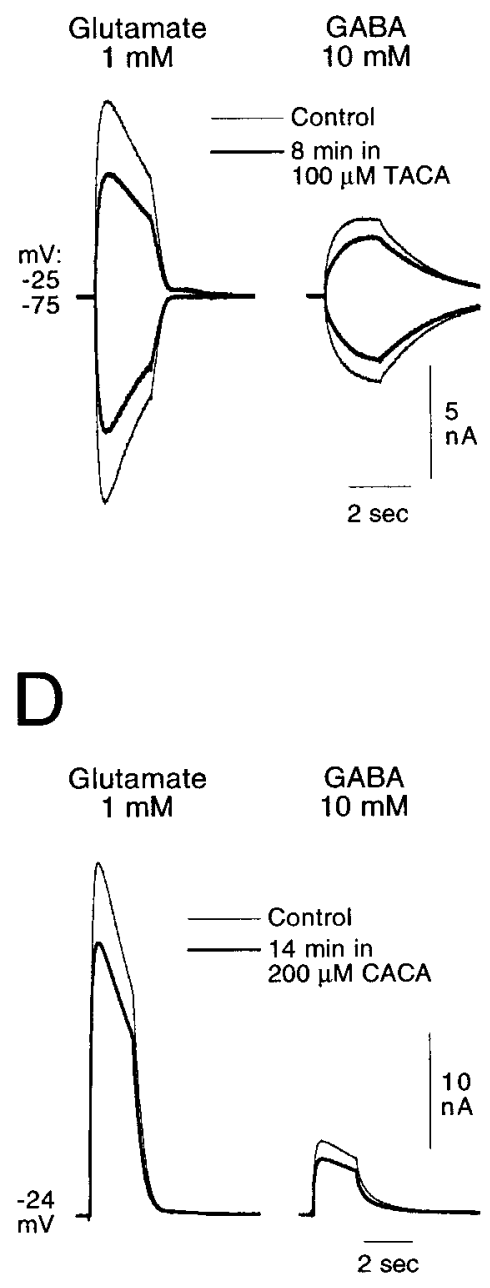

Figure 7. The effect of pharmacological compounds shown to act on either the glutamate- or GABA-induced Cl-dependent responses confirm that the response to GABA in the small pleural cells (Ascher et al., 1978) is mediated by the glutamate receptor. All recordings were made in twoelectrode voltage clamp with cells held at fixed potentials (see figure for values). $A$, The response to both $1 \mathrm{~mm}$ glutamate and $10 \mathrm{~mm}$ GABA were markedly reduced by $50 \mu \mathrm{M} \quad \beta$-alanine applied through the control tube (response to glutamate reduced to $12.5 \%$ of control with $\sigma=0.86 \%$; that to GABA was reduced to $16.7 \%$ of control with $\sigma=$ $4.04 \% ; n=3 ; p=0.156)$. $B$, Both the response to 1 mM glutamate and that to $10 \mathrm{~mm}$ GABA were only weakly reduced by $100 \mu \mathrm{M}$ TACA applied through the control tube (response to glutamate reduced to $69.7 \%$ of control with $\sigma=6.51 \%$; that to GABA reduced to $71.3 \%$ of control with $\sigma=5.69 \% ; n=3$; $p=0.755) . C$, Hypotaurine applied through the control tube blocked both the response to $1 \mathrm{~mm}$ glutamate and that to $10 \mathrm{~mm}$ GABA (response to glutamate reduced to $19.2 \%$ of control with $\sigma=$ $11.3 \%$; that to GABA reduced to $21.7 \%$ of control with $\sigma=2.89 \% ; n=3, p=0.729)$. $D$, CACA $(200$ $\mu \mathrm{M})$ applied through the control tube only weakly blocked the response to both $1 \mathrm{~mm}$ glutamate and $10 \mathrm{~mm}$ GABA (response to glutamate reduced to $82 \%$ of control with $\sigma=3.46 \%$; that to GABA reduced to $79.7 \%$ of control with $\sigma=1.53 \% ; n=3$; $p=0.346)$. response to glutamate seen in the medial and buccal cells (see figure legend for a statistical evaluation of these findings). This suggests that it is mediated by the glutamate-sensitive $\mathrm{Cl}$ channel and that the GABA-gated $\mathrm{Cl}$ receptor-channel complex is not expressed in these cells.

As was seen in Figure $6 A$, GABA activation of the glutamate receptor yields a response that is much smaller than that elicited by the same concentration of glutamate (for $n=3$, the average response to $1 \mathrm{~mm}$ GABA is $3.83 \%$ that of the response to $1 \mathrm{~mm}$ glutamate). Nevertheless, there appears to be little difference in the concentrations of the two amino acids needed to elicit a threshold response via the glutamate receptor. When testing 20 and $50 \mu \mathrm{M}$ glutamate and 20 and $100 \mu \mathrm{M}$ GABA on the pleural cells, no response could be elicited with $20 \mu \mathrm{M}$ of either agonist. A response was elicited by $50 \mu \mathrm{M}$ glutamate in all five cells (average of 1268 pA), whereas $100 \mu \mathrm{M}$ GABA elicited a response (average of 142 pA) in four of the five cells. The fifth cell responded to $200 \mu \mathrm{M}$, the next higher concentration tested.

\section{$G A B A$ activation of the glutamate receptor explains the observation of cross-desensitization}

Cross-desensitization between transmitter-activated $\mathrm{Cl}$ channels has been described frequently in both vertebrate and invertebrate preparations (invertebrate, Franke et al., 1986; Zufall et al., 1988; King and Carpenter, 1987, 1989; vertebrate, Barker and McBurney, 1979; Choquet and Korn, 1988; Krishtal et al., 1988; Baev et al., 1992; Lewis and Faber, 1993; Trombley et al., 1999). In view of the finding that GABA can activate the glutamate receptor mediating the $\mathrm{Cl}$-dependent response, it is not surprising to see that
GABA has a desensitizing-blocking effect on the response to glutamate. Even at low concentrations (e.g., 1 and $10 \mu \mathrm{M}$, which induce no visible current in cells having only the glutamate receptor), GABA significantly reduces the glutamate response in all cells expressing the glutamate receptor (pleural, medial, and buccal cells) (Fig. 8, recordings from a pleural cell). After application of a given GABA concentration, the glutamate response was allowed to stabilize, and all measurements describing the diminution of the glutamate response by GABA refer to such "stabilized" responses. The diminution in the glutamate response increased with increasing concentrations of GABA (Fig. 8). No statistical differences were seen in the percent diminution in these stabilized responses for a given concentration of GABA, whether or not that concentration had been preceded by another, weaker concentration or applied singly ( $t$ tests comparing such experiments yielded $p=$ 0.385 for $10 \mu \mathrm{M}$ GABA and $p=0.305$ for $100 \mu \mathrm{M}$ GABA). Consequently, for describing the diminution in the glutamate response as a function of GABA concentration, all data for a given concentration have been lumped together. The response to $1 \mathrm{~mm}$ glutamate in $1 \mu \mathrm{M}$ GABA was reduced to $85.1 \%$ of the control amplitude $(\sigma=7.16 \% ; n=7)$, in $10 \mu \mathrm{M}$ GABA to $70.2 \%(\sigma=$ $11.8 \% ; n=7)$, and in $100 \mu \mathrm{M}$ GABA to $34.9 \%(\sigma=4.22 \% ; n=8)$.

It should be mentioned at this point that changes in $\mathrm{E}_{\mathrm{Cl}}$ cannot account for the GABA-induced diminutions in the amplitude of the glutamate response: (1) $\mathrm{E}_{\mathrm{Cl}}$ was continually monitored, and evaluations of the glutamate response were always made at a holding potential of a constant distance from $\mathrm{E}_{\mathrm{Cl}}$; (2) application of GABA had the same desensitizing effect on the glutamate response at $\mathrm{E}_{\mathrm{Cl}}$ and at less negative potentials; (3) GABA had a marked 
Effect of 1,10 , and $100 \mu \mathrm{M}$ GABA on response to $1 \mathrm{mM}$ Glutamate

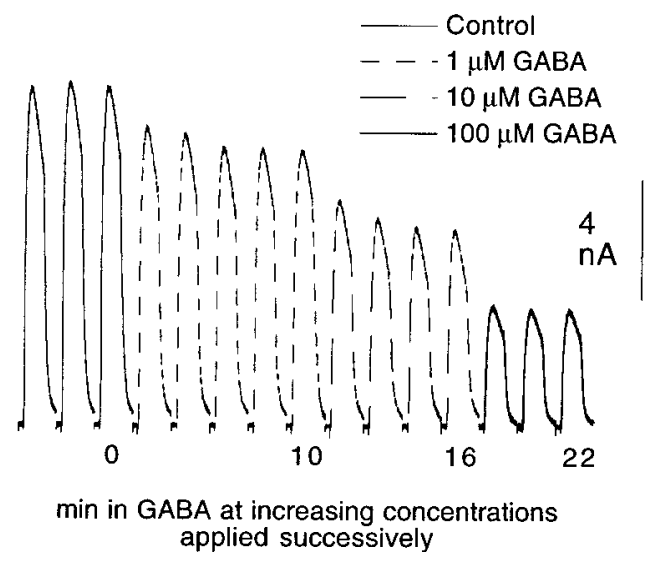

Figure 8. Effect of GABA on the response of a pleural cell to $1 \mathrm{~mm}$ glutamate recorded in two-electrode voltage clamp. Increasing concentrations of $\operatorname{GABA}(1,10$, and $100 \mu \mathrm{M})$ applied successively through the control tube caused an increasing diminution in the response of a pleural cell to 1 $\mathrm{mm}$ glutamate. Notice that no GABA-induced change in holding potential can be detected. The cell was held at $20 \mathrm{mV}$ less negative than $\mathrm{E}_{\mathrm{Cl}}$. See Results for a detailed résumé of related experiments. The response to $1 \mathrm{~mm}$ glutamate in $1 \mu \mathrm{M}$ GABA was reduced to $85.1 \%$ of the control amplitude $(\sigma=7.16 \% ; n=7)$, in $10 \mu \mathrm{M}$ GABA to $70.2 \%(\sigma=11.8 \% ; n=7)$, and in $100 \mu \mathrm{M}$ GABA to $34.9 \%(\sigma=4.22 \% ; n=8)$.

desensitizing effect at concentrations that elicited no current in the cell in which the glutamate responses were being evaluated; and (4) in many neurons (e.g., the medial cells), whereas a $\mathrm{Cl}$ current gated by the GABA receptor blocked the glutamate response, a similar $\mathrm{Cl}$ current gated by the glutamate receptor failed to affect the GABA response.

Likewise, it should be pointed out that an action of GABA on presynaptic neurons can be rejected as a possible source for the cross-desensitization effect. A number of similar experiments (data not shown) performed here on isolated cells in culture confirmed completely the findings from cells in the intact ganglion. Furthermore, the experiments of King and Carpenter (1987) and Oyama et al. (1990), both of which showed similar GABA-induced diminution in glutamate responses, were performed on isolated cells.

Although GABA clearly desensitizes-blocks the glutamateinduced Cl-dependent response, it has no effect on either the glutamate-induced cationic or the glutamate-induced K-dependent response (three experiments made for each response type; data not shown).

\section{Cells in which the GABA but not the glutamate receptor is expressed reveal that glutamate cannot activate the GABA receptor}

There are identifiable cells in the cerebral ganglion in which GABA, but not glutamate, elicits a Cl-dependent response. The response to glutamate in these cells is a pure cationic one and that to GABA is a pure Cl-dependent one, as illustrated in Figure $9 A$, first column. Although, as has been shown above, GABA can effectively activate (Figs. 6, 7) and block (Fig. 8) the glutamate Cl-dependent response, the opposite is not true. In Figure $9 A$, glutamate added to the control tube completely desensitized the glutamate excitatory response in the cerebral cells but had no effect on the GABA Cl-dependent response (Oyama et al., 1990). Even at a $10 \mathrm{~mm}$ concentration, glutamate failed to elicit an increase in $\mathrm{Cl}$ conductance in these cells and failed to diminish the GABAinduced $\mathrm{Cl}$-dependent response (mean response to $1 \mathrm{~mm}$ GABA in the presence of $10 \mathrm{~mm}$ glutamate for four experiments was $100 \%$ of control; $\sigma=2.36 \%$ ).

The failure of glutamate to block the $\mathrm{Cl}$-dependent response to GABA can also be seen in the medial cells in which both glutamate and GABA receptors mediating $\mathrm{Cl}$-dependent responses are ex- pressed (Fig. 9B) (mean response to $1 \mathrm{~mm}$ GABA in the presence of $1 \mathrm{~mm}$ glutamate for four experiments was $102 \%$ of control; $\sigma=$ $2.46 \%$ ). See the figure legend of Figure $9, A$ and $B$, for a more detailed description.

It was mentioned above when discussing the agonist activity of $\beta$-alanine on the glutamate receptor that $\beta$-alanine could, at higher concentrations, activate the GABA receptor. The cerebral cells used for Figure $9 A$ permitted the confirmation of this activation, because $\beta$-alanine in these cells elicited a weak voltage-dependent response that was unaffected by $1 \mathrm{~mm}$ glutamate and markedly blocked by 100 $\mu \mathrm{M}$ TACA, all of these findings consistent with the hypothesis that $\beta$-alanine in these cells was activating, albeit weakly, the GABA receptor. Because the response to $1 \mathrm{~mm} \beta$-alanine in these cells was very weak $(\sim 3 \%$ of that to $1 \mathrm{~mm}$ GABA), the analyses of this response were made using $10 \mathrm{~mm} \beta$-alanine. The amplitude of the response in the cerebral cells to $10 \mathrm{~mm} \beta$-alanine was $\sim 21 \%$ of that to $1 \mathrm{~mm}$ GABA $(n=3 ; \sigma=4.77 \%)$. The mean percent inward to outward current $(n=3)$ for $\beta$-alanine in these cells was indistinguishable from that for GABA (51.3 and $52.3 \%$, with $\sigma=2.52 \%$ and $1.15 \%$, for $\beta$-alanine and GABA, respectively, measured at $20 \mathrm{mV} \pm$ $\mathrm{E}_{\mathrm{Cl}}$ ). Comparing these results with the $\beta$-alanine response in cells having only the glutamate receptor (Fig. 3) reveals the preferential, but incompletely selective, activation by $\beta$-alanine of the glutamate receptor.

In cells in which the glutamate receptor is highly expressed, the response to $1 \mathrm{mM} G A B A$ often contains a detectable component mediated by the glutamate receptor

In light of the finding that GABA can activate the glutamate receptor (Figs. 6, 7), it is interesting to turn our attention to the differences in kinetics of the response to $1 \mathrm{~mm}$ GABA in the medial versus buccal neurons. The expression of the glutamate-gated $\mathrm{Cl}$ channel is much greater in the buccal than in the medial cells, with the response to $1 \mathrm{~mm}$ glutamate being typically approximately twice that to $1 \mathrm{~mm}$ GABA in the buccal cells, and vice versa in the medial cells.

In the medial cells, the decay of the response to $1 \mathrm{~mm}$ GABA is almost always smooth, with no change in rate of decay manifested at the end of the $2 \mathrm{sec}$ GABA pulse (Figs. $1 A, 9 B$ ). At this concentration, the decay appears to depend exclusively on the "off rate" of the desensitized GABA receptor. That is not the case for the response to glutamate, which shows a sharp change in decay rate when the control flow replaces the agonist flow.

In the buccal cells, on the other hand, the response to $1 \mathrm{~mm}$ GABA often shows an "atypical" decay (Figs. $1 B, 9 C$ ). As can be seen in Figure $9 C^{\prime}$, the "hump" sometimes seen in the GABA response of the buccal cells disappears with a "desensitizing" application of $100 \mu \mathrm{m}$ glutamate in the control tube, leaving a decay typical of the GABA response mediated by the voltage-dependent, sulfate-sensitive GABA receptor. The transformation in the GABA response in the presence of $100 \mu \mathrm{M}$ glutamate was evaluated by approximating the integrals of the GABA responses in the presence and absence of $100 \mu \mathrm{M}$ glutamate and subtracting these integrals. The mean reduction in the control GABA response thus obtained was $10.3 \%(n=6 ; \sigma=3.94 \%)$. This $10 \%$ diminution by $100 \mu \mathrm{M}$ glutamate of the GABA response in some buccal cells should be compared with the total failure of even $10 \mathrm{~mm}$ glutamate to affect the GABA response in the cerebral cells, which are lacking the glutamate receptor. The element of the response desensitized by $100 \mu \mathrm{M}$ glutamate (Fig. 9 $C^{\prime}$, Difference trace) can hence be attributed to a current resulting from the activation by GABA of the glutamate receptor.

\section{Comparison of the amino acid receptors with the two ACh receptors mediating $\mathrm{Cl}$-dependent responses}

It was shown recently by Kehoe and McIntosh (1998) that two pharmacologically distinct receptors mediate the ACh-induced increase in $\mathrm{Cl}$ conductance. One receptor mediates a rapidly desensitizing response, and the other mediates a sustained response. These Cl-dependent cholinergic responses are seen, alongside the 


$$
\text { A }
$$

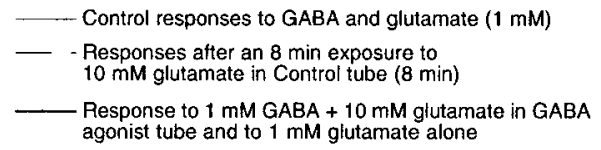

$1 \mathrm{mMGABA}+$

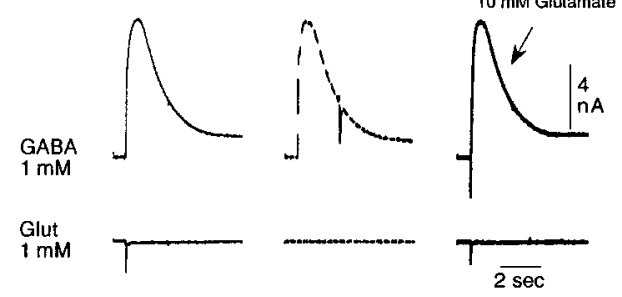

C

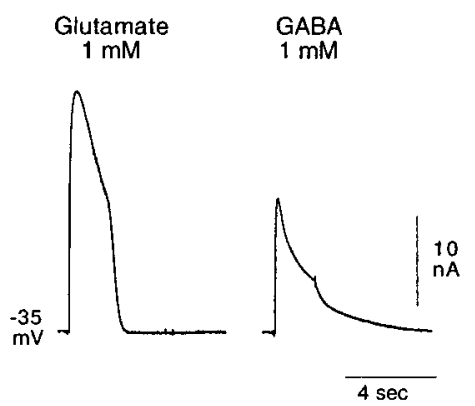

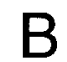

- Control responses to GABA and Gtutamate $(1 \mathrm{mM})$

- Responses after 12 min exposure to $100 \mu \mathrm{M}$ glutamate in Control tube Responses after 12 min exposure to $1 \mathrm{mM}$ glutamate in Control tube

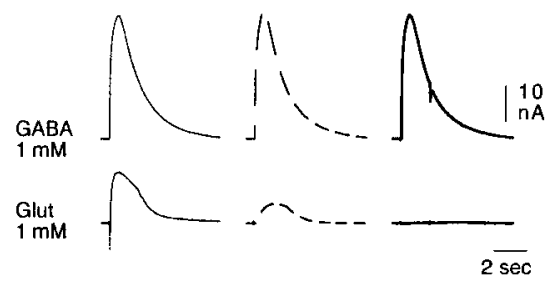

$C^{\prime}$

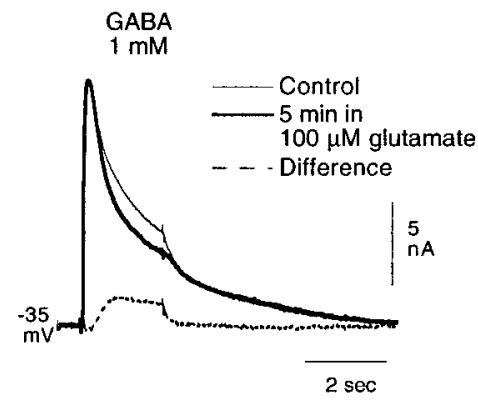

Figure 9. The Cl-dependent response to GABA measured in two-electrode voltage clamp in a cerebral cell $(A)$, a medial cell $(B)$, and a buccal cell $\left(C, C^{\prime}\right)$ in the absence or presence of glutamate. $A$, In the cerebral cell control records, GABA elicits a pure Cl-dependent response (top trace), whereas glutamate elicits a pure cationic current (bottom trace). Glutamate $(10 \mathrm{~mm})$ flowing through the control tube (middle column) desensitized the glutamate cationic current but failed to affect the GABA response. The inward-going current seen on the downswing of the GABA response (middle $G A B A$ record) reveals a recovery from desensitization of the glutamate cationic response, elicited here by the glutamate flowing from the control tube at the end of the $2 \mathrm{sec}$ application of the glutamate-free, 1 mM GABA solution. In the third column, it can be seen that, even when $10 \mathrm{~mm}$ glutamate was added to the $1 \mathrm{mM}$ GABA solution, there was no blocking effect of glutamate on the GABA response. Note that the response to the glutamate-GABA agonist application is biphasic, consisting of a cationic response elicited by $10 \mathrm{~mm}$ glutamate and a Cl-dependent response elicited by 1 mM GABA. B, Responses to GABA (top trace) and glutamate (bottom trace) recorded from a medial cell in the absence and presence of $100 \mu \mathrm{M}$ or $1 \mathrm{~mm}$ glutamate flowing through the control tube. Note that both the cationic and Cl-dependent response to glutamate were desensitized by the glutamate in the control tube, whereas no desensitizing or blocking effect of the glutamate can be detected on the response to GABA. The presence of $1 \mathrm{~mm}$ glutamate in the control tube can be detected on the downswing of the GABA response ( $f$ -

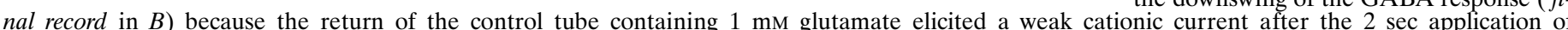

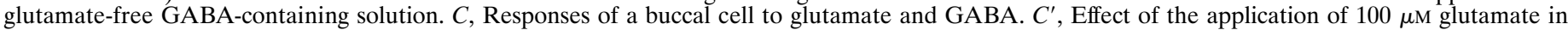

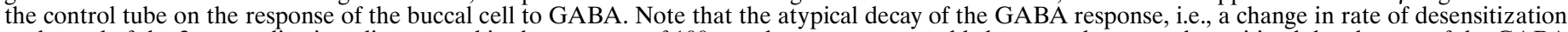

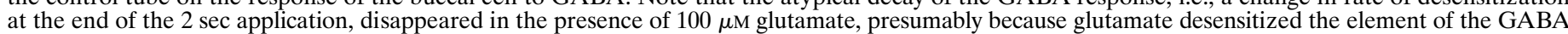
response that was mediated by the glutamate receptor (Difference).

glutamate- and GABA-induced $\mathrm{Cl}$ responses, in the medial cells and in selected buccal cells but are not always associated with them in other cells. For example, on the small pleural cells that express no GABA receptor but do express the glutamate receptor mediating a $\mathrm{Cl}$-dependent response, $\mathrm{ACh}$ elicits a pure cationic response (Ascher et al., 1978).

The ACh-activated conductance, like that activated by glutamate, fails to show a voltage dependence over the range of holding potentials studied here (Kehoe and McIntosh, 1998), and neither of the two Cl-dependent responses elicited by ACh was affected by intracellular sulfate ions (Fig. $10 \mathrm{~A}$ ). Whereas the response to $\mathrm{ACh}$ after perfusion with a sulfate-based pipette solution remained essentially unchanged ( $98.8 \%$ of control; $\sigma=3.4 \%)$, that to GABA was markedly reduced $(35.7 \%$ of control; $\sigma=19 \% ; n=3$; $p=0.005)$.

The pharmacology of the $\mathrm{Cl}$-dependent $\mathrm{ACh}$ responses has been described in detail by Kehoe and McIntosh (1998) in which the effects of $100 \mu \mathrm{M}$ TC and strychnine can be seen. MLA, like $\alpha$-bungarotoxin (Kehoe and McIntosh, 1998), blocked both of the cholinergic $\mathrm{Cl}$-dependent responses but had no effect on either the glutamate- or GABA-induced responses (Fig. 10B, records taken from a buccal cell). The ACh response in MLA, measured at the time corresponding to the peak of the control $\mathrm{ACh}$ response, was only $1 \%$ of the control $(n=3 ; \sigma=0.5 \%)$; the responses to glutamate and GABA in the presence of MLA were $103 \%(\sigma=$ $0.58 \%)$ and $102 \%(\sigma=3.4 \%)$ of control, respectively, for the two sets of responses. Neither glutamate nor GABA desensitizedblocked the ACh responses (Fig. 10C, $C^{\prime}$ ), and ACh, in turn, had no desensitizing-blocking effect on the responses to the two amino acids (Fig. 10D, $D^{\prime}$ ) (Ikemoto and Akaike, 1988). These latter experiments, however, had to be performed in cells that did not respond to $\mathrm{ACh}$ with a strong nondesensitizing $\mathrm{Cl}$ current (Kehoe and McIntosh, 1998). In a cell in which such persistent outward ACh-induced currents exist, the application of either glutamate or GABA solutions (which did not contain ACh) would cause a change in current because of the washing off of ACh, giving a false estimation of either the GABA- or glutamate-activated current. Statistical analyses of the results illustrated in Figure 10 are presented in the figure legend.

\section{DISCUSSION}

The experiments described here have shown that the receptorchannel complexes mediating the $\mathrm{Cl}$-dependent responses to glutamate, GABA, and ACh in Aplysia neurons are independent entities. Nevertheless, cross-desensitization does occur between the GABA and glutamate responses and was shown to result exclusively from the ability of GABA to interact with the glutamate receptor.

These findings are compatible with the results obtained by King and Carpenter (1987) but not with their conclusion that the glutamate and GABA responses gate the same receptor-channel complex. On the other hand, our results are incompatible with those of Ikemoto and Akaike (1988), who saw no interactions between the GABA and glutamate responses. These same authors participated in a later study (Oyama et al., 1990) in which interactions were seen, and GABA was shown to elicit both a low-threshold and a high-threshold response. In the 1990 study (Oyama et al.), the authors proposed that the high-threshold GABA response they observed was attributable to the activation, by GABA, of the glutamate receptor, a hypothesis confirmed by the results presented here. 
A

Progressive and selective block of GABA response recorded with $\mathrm{K}_{2} \mathrm{SO}_{4}$ inside solution

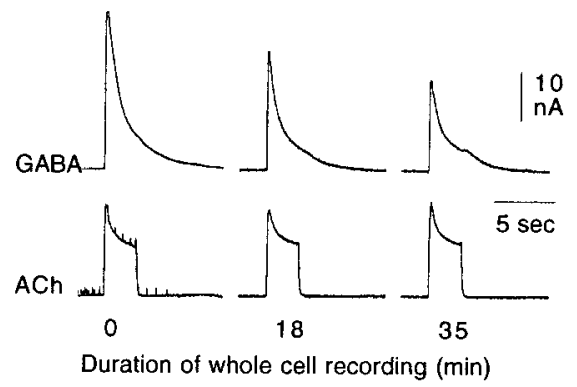

Figure 10. Comparison of the amino acid Cl-dependent responses with the cholinergic Cl-dependent response. $A$, Recordings from a buccal cell in whole-cell voltage clamp with $\mathrm{K}_{2} \mathrm{SO}_{4}$-based internal solution of responses to $500 \mu \mathrm{M}$ GABA and $500 \mu \mathrm{M}$ $\mathrm{ACh}$. These records were taken at a holding potential $20 \mathrm{mV}$ less negative than $\mathrm{E}_{\mathrm{Cl}}$ and show that the whole-cell perfusion with a sulfate-containing internal solution selectively diminished the GABA response. $B$, MLA blocked the ACh-induced $\mathrm{Cl}$-dependent responses at $2 \mu \mathrm{M}$ but had no effect, even at $10 \mu \mathrm{M}$, on the responses to either glutamate or GABA. These responses were recorded from buccal cells in two-electrode voltage clamp. $C, C^{\prime}$, Neither $1 \mathrm{~mm}$ glutamate $(C)$ nor $1 \mathrm{~mm}$ GABA $\left(C^{\prime}\right)$ added to the control tube affected the response to $200 \mu \mathrm{M} \mathrm{ACh}$ recorded in twoelectrode voltage clamp from a buccal cell. The peak ACh response in the presence of $1 \mathrm{~mm}$ glutamate was $99.7 \%$ of the control $(\sigma=3.9 \% ; n=5)$, and the peak ACh response in the presence of $1 \mathrm{~mm}$ GABA was $97.9 \%$ of the control $(\sigma=3.47 \% ; n=$ 5). $D, D^{\prime}, \mathrm{ACh}(200 \mu \mathrm{M})$ had no effect on either the glutamate $(D)$ or GABA $\left(D^{\prime}\right)$ response recorded from a buccal cell in two-electrode voltage clamp. The mean peak responses to both glutamate and GABA in the presence of $200 \mu \mathrm{M} \mathrm{ACh}$ were $99.7 \%$ of control $(\sigma=2.08$ and $1.53 \%$ for glutamate and GABA, respectively; $n=3)$.
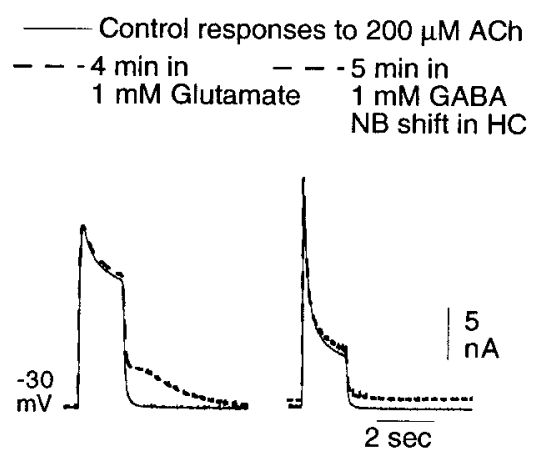

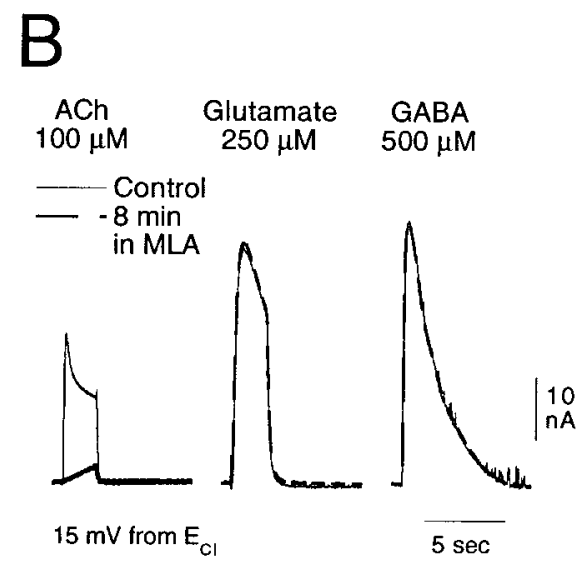

$D, D^{\prime}$

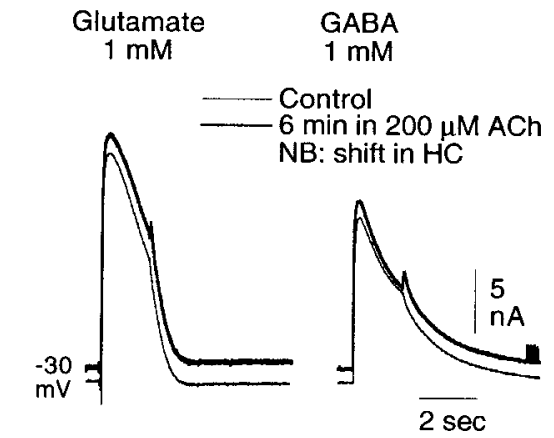

\section{Glutamate and GABA activation of the glutamate receptor}

In our study, the concentrations of GABA and glutamate required for threshold activation of the glutamate receptor were found to be remarkably similar. That is, to consistently obtain a discernible response to glutamate, a concentration of $50 \mu \mathrm{M}$ was needed; GABA was shown to activate the same receptor at only twice that concentration. In contrast, the average currents elicited by 1 and 10 mM GABA in cells having only the glutamate receptor (Fig. $6 A, B$ ) were only $\sim 4$ and $36 \%$, respectively, of the response of the same cell to $1 \mathrm{~mm}$ glutamate.

The low concentrations of GABA that are able to affect the sensitivity of the glutamate receptor (Fig. 8) suggest that, if both GABA and glutamate receptors are coexpressed on the same subsynaptic membrane, liberation of GABA on that membrane would be able to cross-desensitize the glutamate receptor. The protocol used here did not permit an evaluation of the kinetics of the GABA-induced desensitization. However, from the work of Oyama et al. (1990), it is clear that a $10 \mathrm{sec}$ application of $300 \mu \mathrm{M}$ GABA is sufficient to cause a very marked diminution in the response to the same concentration of glutamate.

Although the data strongly suggest that direct activation by GABA of the glutamate receptor mediates the crossdesensitization process, the molecular mechanism by which GABA and $\beta$-alanine desensitize the glutamate receptor remains to be established. The fact that the response to glutamate shows autodesensitization suggests that there exists a "desensitized state" of the glutamate receptor, and GABA and $\beta$-alanine may act by favoring the transition toward this state. However, the strength of the cross-desensitization appears to be correlated with neither the strength of activation by the "inhibiting" compound nor the rate of desensitization it induces in the "inhibited" receptor. The inhibi- tion induced by GABA and $\beta$-alanine may be, to some degree, a partial agonist effect. That is, GABA and $\beta$-alanine may compete with glutamate for binding to the same site and inhibit the glutamate response because they induce a much lower probability of opening of the channels.

\section{Relationship between the invertebrate glutamate receptor and the vertebrate glycine receptor}

The invertebrate glutamate receptors gating $\mathrm{Cl}$ channels that have thus far been cloned show greater resemblance to the vertebrate glycine receptor than to any other receptor (Cully et al., 1994; Vassilatis et al., 1997). Furthermore, no one has reported evidence for a glycine-gated $\mathrm{Cl}$ channel in invertebrate neurons. Conversely, the only glutamate-gated $\mathrm{Cl}$ channels thus far seen in vertebrates appear to be associated with glutamate transporters (for review, see Fairman and Amara, 1999). It thus appears reasonable to relate the invertebrate glutamate receptors to the vertebrate glycine receptors. Despite the failure of the glutamate receptor studied here to be blocked by $100 \mu \mathrm{M}$ strychnine, its sensitivity to $\beta$-alanine reinforces this parallel (Wu et al., 1993; Jonas et al., 1998).

A recent study evaluating the differential activation by glycine and GABA of a recombinant homomeric glycine receptor revealed a 200- to 300-fold difference in the $\mathrm{EC}_{50}$ values of the activation curves for the two amino acids (Fucile et al., 1999). In contrast, in a study measuring the activity of GABA and glycine on a recombinant homomeric human GABA $\rho$ receptor, the difference in sensitivity to the two amino acids was much greater, on the order of 10,000-fold (Calvo and Miledi, 1995).

In previously published experiments on isolated Aplysia neurons, concentration-response curves were obtained for the glutamate response (Ikemoto et al., 1988b) and for the high-threshold GABA response hypothesized to be mediated by the glutamate receptor 
(Oyama et al., 1990) and yielded $\mathrm{EC}_{50}$ values of 130 and $\sim 6 \mathrm{~mm}$, respectively. The difference in $\mathrm{EC}_{50}$ values is higher $(\sim 46$-fold) than that between the threshold values referred to above (twofold), probably because of a smaller Hill coefficient of the GABA response. Yet the difference is surprisingly small compared with the failure of even very high concentrations of glutamate $(10 \mathrm{~mm})$ to activate the GABA receptor, for which the $\mathrm{EC}_{50}$ for activation by GABA was estimated to be $64 \mu \mathrm{M}$ (Ikemoto et al. (1988a).

These studies together suggest a high selectivity of both the vertebrate and invertebrate GABA receptor, whereas both the vertebrate glycine receptor and the invertebrate glutamate receptor show some sensitivity to GABA.

However, many molecular variations of GABA and glycine receptors exist in vertebrate neurons, and this diversity may explain the wide range of findings concerning cross-desensitization between these ligand-gated $\mathrm{Cl}$ channels. For example, whereas Choquet and Korn (1988) found no interaction between GABA and glycine responses in cultured chick spinal neurons, Baev et al. (1992), studying lamprey spinal cord neurons, found that there was total cross-desensitization between the responses to the same amino acids. They concluded that only one receptor-channel complex, responding to both amino acids, was expressed on these neurons. Recently, Trombley et al. (1999) described all possible cross-desensitization profiles between GABA and glycine responses in rat olfactory bulb neurons in primary culture, with the profile depending on the neuron studied. Their findings suggest that more than one type of receptor for each amino acid is expressed in these cells.

A similar diversity must exist in invertebrate neurons because, whereas the glutamate receptor of molluscs is desensitized by even low concentrations of GABA, no interaction between the two amino acid responses is seen in some invertebrate ganglionic neurons (lobster, Cleland and Selverston, 1998; crab, Duan and Cooke, 2000).

\section{The ACh-activated receptor-channel complex}

Although we have no data that permit us to discriminate between the properties of the ACh-gated channel(s) (Kehoe and McIntosh, 1998) and those of the glutamate-gated channel, the fact that the $\mathrm{ACh}$ and glutamate receptor channel complexes are not consistently coexpressed permits us to conclude that, even if the channels per se are identical, the receptor-channel complexes for the different transmitters are distinct molecular entities.

\section{$\mathrm{GABA}_{\mathrm{A}}$ or $\mathrm{GABA}_{\mathrm{C}}$ ?}

The object of the pharmacological evaluation of the GABA receptor in this study was primarily to differentiate it from the receptor underlying the glutamate response. However the finding that TACA is a more effective agonist than CACA suggests that the molluscan GABA receptor resembles the $\mathrm{GABA}_{\mathrm{C}}$ rather than the $\mathrm{GABA}_{\mathrm{A}}$ receptor (Johnston, 1996), a conclusion likewise drawn from previous studies showing that the molluscan receptor is not blocked by bicuculline and is not potentiated by either diazepam (Ikemoto et al., 1988a; Kim and Takeuchi, 1990) or pentobarbital (Ikemoto et al., 1988a) (but see Kim and Takeuchi, 1990). The molluscan GABA receptor desensitizes rapidly, a characteristic associated with the $\mathrm{GABA}_{\mathrm{A}}$ receptor. However, rapidly desensitizing $\mathrm{GABA}_{\mathrm{C}}$ receptors have been described recently in vertebrates (Han et al., 1997; Boué-Grabot et al., 2000).

\section{Sulfate blockade of the GABA channel}

The observation made here that intracellular sulfate ions selectively block the GABA response was exploited in these experiments as a "tool" for differentiating the GABA receptor-channel complex from the glutamate and ACh receptor-channel complexes, and the means by which this blockade occurs have not as yet been examined. However, the block is clearly independent of voltage over the range tested (Fig. $2 B$ ). Furthermore, a differential permeability of the GABA receptor channel to sulfate ions cannot explain its differential sensitivity to internal sulfate. It was shown previously (Kehoe, 1972a) that sulfate cannot pass through the channels opened by $\mathrm{ACh}$, and it was shown here that partial substitution of intracellular $\mathrm{Cl}$ by sulfate alters the inversion potential of all three agonist-induced responses to the same extent.

\section{REFERENCES}

Ascher P, Marty A, Neild TO (1978) The mode of action of antagonists of the excitatory response to acetylcholine in Aplysia neurones. J Physiol (Lond) 278:207-235.

Baev KV, Rusin KI, Safronov BV (1992) Primary receptor for inhibitory transmitters in lamprey spinal cord neurons. Neuroscience 46:931-941.

Barker JL, McBurney RN (1979) GABA and glycine may share the same conductance channel on cultured mammalian neurones. Nature 277:234-236.

Boué-Grabot E, Taupignon A, Tramu G, Garret M (2000) Molecular and electrophysiological evidence for a GABAC receptor in thyrothropinsecreting cells. Endocrinology 141:1627-1632.

Calvo DJ, Miledi R (1995) Activation of $\mathrm{GABA}_{\rho 1}$ receptors by glycine and $\beta$-alanine. NeuroReport 6:1118-1120.

Choquet D, Korn H (1988) Does $\beta$-alanine activate more than one chloride channel associated receptor? Neurosci Lett 84:329-334.

Cleland TA, Selverston AI (1998) Inhibitory glutamate receptor channels in cultured lobster stomatogastric neurons. J Neurophysiol 79:3189-3196.

Cully DF, Vassilatis DK, Liu KK, Paress PS, van der Ploeg LHT, Schaeffer JM, Arena JP (1994) Cloning of an avermectin sensitive glutamategated chloride channel from Caenorhabditis elegans. Nature 371:707-711.

Duan S, Cooke IM (2000) Glutamate and GABA activate different receptors and $\mathrm{Cl}-$ conductances in crab peptide-secretory neurons. J Neurophysiol 83:31-37.

Fairman WA, Amara SG (1999) Functional diversity of excitatory amino acid transporters: ion channel and transport modes. Am J Physiol [Review] 277:F481-F486.

Franke Ch, Hatt H, Dudel J (1986) The inhibitory chloride channel activated by glutamate as well as by $\gamma$-amino-butyric acid (GABA). J Comp Physiol [A] 159:591-609.

Fucile S, de Saint Jan D, David-Watine D, Korn H, Bregestovski P (1999) Comparison of glycine and GABA actions on the zebrafish homomeric glycine receptor. J Physiol (Lond) 517:369-383.

Gardner D, Kandel ER (1977) Physiological and kinetic properties of cholinergic receptors activated by multiaction interneurons in buccal ganglia of Aplysia. J Neurophysiol 40:333-348.

Hamill O, Marty A, Neher E, Sakmann B, Sigworth F (1981) Improved patch-clamp techniques for high-resolution current recording from cells and cell-free membrane patches. Pflügers Arch 391:85-100.

Hamill OP, Bormann J, Sakmann (1983) Activation of multipleconductance state chloride channels in spinal neurons by glycine and GABA. Nature 305:805-808.

Han MH, Li Y, Yang XL (1997) Desensitizing GABA $_{C}$ receptors on carp retinal bipolar cells. NeuroReport 14:1331-1335.

Ikemoto Y, Akaike N (1988) The glutamate-induced chloride current in Aplysia neurones lacks pharmacological properties seen for excitatory responses to glutamate. Eur J Pharmacol 150:313-318.

Ikemoto Y, Akaike N, Kijima H (1988a) Kinetic and pharmacological properties of the GABA-induced chloride current in Aplysia neurones: a "concentration clamp" study. Br J Pharmacol 95:883-895.

Ikemoto Y, Akaike N, Ono K (1988b) Kinetic analysis of glutamateinduced chloride current in Aplysia neurones: a "concentration clamp" study. Eur J Pharmacol 150:303-311.

Johnson J, Ascher P (1987) Glycine potentiates the NMDA response in cultured mouse brain neurons. Nature 325:529-531.

Johnston GAR (1996) GABA $_{C}$ receptors: relatively simple transmittergated ion channels? Trends Pharmacol 17:319-323.

Jonas P, Bischofberger J, Sandkühler J (1998) Corelease of two fast neurotransmitters at a central synapse. Science 281:419-424.

Katz PS, Levitan IB (1993) Quisqualate and ACPD are agonists for a glutamate-activated current in identified Aplysia neurons. J Neurophysiol 69:143-150.

Kehoe JS (1972a) Ionic mechanism of a two component cholinergic inhibition in Aplysia neurons. J Physiol (Lond) 225:85-114.

Kehoe JS (1972b) Three acetylcholine receptors in Aplysia neurones. J Physiol (Lond) 225:115-146.

Kehoe JS (1978) Transformation by concanavalin A of the response of molluscan neurones to L-glutamate. Nature 274:866-869.

Kehoe JS (1985) Synaptic block of a transmitter-induced potassium conductance in Aplysia neurones. J Physiol (Lond) 369:399-437.

Kehoe JS (1994) Glutamate activates a K+ conductance increase in Aplysia neurons that appears to be independent of $G$ proteins. Neuron 13:691-702.

Kehoe JS, McIntosh JM (1998) Two distinct nicotinic receptors, one pharmacologically similar to the vertebrate $\alpha 7$-containing receptor, mediate Cl currents in Aplysia neurons. J Neurosci 8:8198-8213.

Kim KH, Takeuchi H (1990) Pharmacological characteristics of two different types of inhibitory GABA receptors on Achatina fulica neurones. Eur J Pharmacol 182:49-62.

King WM, Carpenter DO (1987) Distinct GABA and glutamate recep- 
tors may share a common channel in Aplysia neurons. Neurosci Lett 82:343-348

King WM, Carpenter DO (1989) Voltage-clamp characterization of Clconductance gated by GABA and L-glutamate in single neurons of Aplysia. J Neurophysiol 61:892-899.

Krishtal OA, Osipchuk YV, Vrublevsky SV (1988) Properties of glycine activated conductances in rat brain neurons. Neurosci Lett 84:271-276.

Lewis CA, Faber DS (1993) GABA responses and their partial occlusion by glycine in cultured rat medullar neurons. Neuroscience 52:83-96.

Matsumoto M (1982) The voltage-dependent nature of the GABAinduced conductance change recorded from the ganglion cell of Aplysia Jpn J Physiol 32:55-67.

Okamoto K, Sakai Y (1981) Inhibitory actions of taurocyamine, hypotaurine, homotaurine, taurine and GABA on spike discharges of Purkinje cells, and localization of sensitive sites, in guinea pig cerebellar slices Brain Res 206:371-386.

Oyama Y, Ikemoto Y, Kits KS, Akaike N (1990) GABA affects the glutamate receptor-chloride channel complex in mechanically isolated and internally perfused Aplysia neurons. Eur J Pharmacol 185:43-52.
Shirasaki T, Aibara K, Akaike N (1992) Direct modulation of GABA receptor by intracellular ATP in dissociated nucleus tractus solitarii neurones of rat. J Physiol (Lond) 449:551-572.

Swann JW, Carpenter DO (1975) Organisation of receptors for neurotransmitters on Aplysia neurones. Nature 258:751-754.

Trombley PQ, Hill BJ, Horning MS (1999) Interactions between GABA and glycine at inhibitory amino acid receptors on rat olfactory bulb neurons. J Neurophysiol 82:3417-3422.

Vassilatis DK, Elliston KO, Paress PS, Hamelin M, Arena JP, Schaeffer JM, Van der Ploeg LH, Cully DF (1997) Evolutionary relationship of the ligand-gated ion channels and the avermectin-sensitive, glutamategated chloride channels. J Mol Evol 44:501-508.

Wu FS, Gibbs TT, Farb DH (1993) Dual activation of GABA and glycine receptors by $\beta$-alanine: inverse modulation by progesterone and 5 alphapregnan-3 alpha-ol-20-one. Eur J Pharmacol 246:239-246.

Zufall F, Franke Ch, Hatt H (1988) Acetylcholine activates a chloride channel as well as glutamate and GABA. J Comp Physiol [A] 163: $609-620$. 